\begin{tabular}{|c|l|}
\hline Title & Suppression of mast cell degranulation by a novel ceramide kinase inhibitor, the F-12509A olefin isomer K1 \\
\hline Author(s) & $\begin{array}{l}\text { Kim, Jin-W ook; I nagaki, Y Yichi; Mitsutake, Susumu; Maezawa, Nobuhiro; Katsumura, Shigeo; Ryu, Y eon-Woo; Park, } \\
\text { Chang-Seo; Taniguchi, Masaru; Igarashi, Yasuyuki }\end{array}$ \\
\hline Citation & $\begin{array}{l}\text { Biochimica et Biophysica A cta (BBA) - Molecular and Cell Biology of Lipids, 1738(1-3), 82-90 } \\
\text { https://doi.org/10.1016/.bbalip.2005.10.007 }\end{array}$ \\
\hline Issue Date & 2005 \\
\hline Doc URL & http://hdl.handle.net/2115/5800 \\
\hline Type & article (author version) \\
\hline File Information & BBA1738(1-3).pdf \\
\hline
\end{tabular}

Instructions for use 


\section{Suppression of mast cell degranulation by a novel ceramide kinase inhibitor, the F-12509A olefin isomer K1}

Jin-Wook Kim ${ }^{\text {a, b, c, } 1 \text {, Yuichi Inagaki }}{ }^{\mathrm{a}, 1}$, Susumu Mitsutake ${ }^{\mathrm{a}}$, Nobuhiro Maezawa ${ }^{\mathrm{d}}$, Shigeo Katsumura ${ }^{\mathrm{d}}$, Yeon-Woo Ryu ${ }^{\mathrm{b}}$, Chang-Seo Park ${ }^{\mathrm{e}}$, Masaru Taniguchi ${ }^{\mathrm{f}}$, and Yasuyuki Igarashi ${ }^{\mathrm{a}}$

${ }^{a}$ Department of Biomembrane and Biofunctional Chemistry, Graduate School of Pharmaceutical Science, Hokkaido University. Kita 12, Nishi 6, Kita-ku, Sapporo 060-0812, Japan, 'Department of Molecular Science and Technology, Ajou University, San 5, Wonchun-dong, Yeongtong-gu, Suwon 443-749, Korea, 'Doosan Biotech, 39-3, Seongbok-dong, Yongin-si, Gyeonggi-do 449-795, Korea,

${ }^{\mathrm{d} S c h o o l ~ o f ~ S c i e n c e ~ a n d ~ T e c h n o l o g y, ~ K w a n s e i ~ G a k u i n ~ U n i v e r s i t y, ~ G a k u e n, ~ S a n d a, ~ H y o g o ~ 669-1337, ~}$ Japan, 'Department of Chemical and Biochemical Engineering, Dongguk University, 3-26 Pil-dong, Chung-gu, Seoul 100-715, Korea, ${ }^{\mathrm{f}} \mathrm{R}$ KEN Research Center for Allergy and Immunology, Yokohama, Kanagawa 230-0045, Japan

Key words: ceramide, ceramide 1-phosphate, ceramide kinase, inhibitor, degranulation, mast cell

To whom correspondence should be addressed:

Dr. Yasuyuki Igarashi

Department of Biomembrane and Biofunctional Chemistry,

Graduate School of Pharmaceutical Science, Hokkaido University.

Kita 12, Nishi 6, Kita-ku, Sapporo 060-0812, Japan.

Phone: 81-11-706-3970

Fax: 81-11-706-4986

Email address : yigarash@pharm.hokudai.ac.jp 


\section{Abstract}

Antigen-induced degranulation of mast cells plays a pivotal role in allergic and inflammatory responses. Recently, ceramide kinase (CERK) and its phosphorylated product ceramide 1-phosphate (C1P) have emerged as important players in mast cell degranulation. Here, we describe the synthesis of a novel F-12509A olefin isomer, K1, as an effective CERK inhibitor. In vitro kinase assays demonstrated that $\mathrm{K} 1$ effectively inhibits CERK without inhibiting sphingosine kinase and diacylglycerol kinase. Treating RBL-2H3 cells with K1 reduced cellular C1P levels to $40 \%$ yet had no effect on cell growth. Furthermore, treatment with K1 significantly suppressed both calcium ionophore- and IgE/antigen-induced degranulation, indicating that $\mathrm{K} 1$ interferes with signals that happen downstream of $\mathrm{Ca}^{2+}$ mobilization. Finally, we show that $\mathrm{K} 1$ affects neither IgE/antigen-induced global tyrosine phosphorylation nor subsequent $\mathrm{Ca}^{2+}$ elevation, suggesting a specificity for CERK-mediated signals. Our novel CERK inhibitor provides a useful tool for studying the biological functions of CERK and C1P. Moreover, to our knowledge, this is the first report demonstrating that inhibition of CERK suppresses IgE/antigen-induced mast cell degranulation. This finding suggests that CERK inhibitors might be a potential therapeutic tool in the treatment of allergic diseases.

\section{Introduction}

Antigen-induced aggregation of $\operatorname{IgE}$ receptor (FceRI) in mast cells plays a pivotal role in allergic and inflammatory responses. Aggregation of this receptor prompts the recruitment and activation of cytosolic tyrosine kinases and phospholipases $(1,2)$. These cellular events culminate in the exocytosis of granular content and subsequent allergic inflammation, such as that associated with asthma and anaphylaxis. Therefore, regulation of mast cell degranulation is a potential target for anti-allergic therapeutics. 
The breakdown of sphingomyelin (SM) produces bioactive sphingolipid metabolites, including ceramide (CER), sphingosine (SPH), and sphingosine 1-phosphate (S1P). These sphingolipid metabolites play important roles in the regulation of cell proliferation, survival and apoptosis (3-5). In particular, S1P has been implicated as a key factor in modulating mast cells (6), and ceramide 1-phosphate (C1P), which is formed via the phosphorylation of CER by ceramide kinase (CERK), is emerging as an important mediator in mast cell degranulation $(7,8)$. Both CERK and C1P have also been implicated in the regulation of neurotransmitter secretion, theoretically by increasing the fusibility of the vesicle membranes (9), and C1P promotes phagolysosome formation and liposome fusion $(10,11)$. These studies have identified $\mathrm{C} 1 \mathrm{P}$ as a potent mediator for membrane fusion. C1P induces cellular arachidonic acid release in A549 lung adenocarcinoma cells via activation of phospholipase $\mathrm{A}_{2}(12)$.

Human CERK was recently cloned based on its sequence homology to sphingosine kinase type 1 (SPHK1) (13). CERK has an N-terminal plecstrin homology (PH) domain and a C-terminal $\mathrm{Ca}^{2+} /$ calmodulin binding domain, and is activated by $\mathrm{Ca}^{2+}(9)$. Furthermore, the $\mathrm{Ca}^{2+} /$ calmodulin binding domain is essential for the $\mathrm{Ca}^{2+}$-induced activation (14). Such an increase in CERK activity, attributable to elevations in intracellular $\mathrm{Ca}^{2+}$ levels, has been observed in rat basophilic leukemia cells following IgE/antigen treatment (7). Moreover, both the calcium-induced CERK activation and the formation of $\mathrm{C} 1 \mathrm{P}$ were found to be necessary steps in calcium ionophore-induced mast cell degranulation (7).

Some sphingosine kinase inhibitors are known to modestly inhibit CERK at high concentrations in vitro (13). However, to date, no specific and effective CERK inhibitor has been reported. Although C2-ceramide has been used to inhibit CERK activity (7), it is also known to inhibit protein kinase $\mathrm{C}$ and IgE/antigen-induced phospholipase D (PLD) activation (15-17). Furthermore, C2-ceramide is unsuitable as a therapeutic tool for allergic diseases, because of its high cytotoxicity $(18)$.

In our search of novel CERK inhibitors, we have developed analogs of F-12509A, a 
previously reported SPHK inhibitor (19). We have identified an olefin isomer of F-12509A that effectively and specifically inhibits CERK activity. Furthermore, this new CERK inhibitor suppresses RBL-2H3 mast cell degranulation, suggesting that this and other CERK inhibitors could be a potent therapeutic tool for allergic diseases.

\section{Materials and methods}

\section{1. Synthesis and characterization of F-12509A and its analogs (Scheme 1, 2)}

\section{Alcohol 3}

To a solution of acetonide $3(1.388 \mathrm{~g}, 6.244 \mathrm{mmol})$ in tetrahydrofuran $(30 \mathrm{~mL})$ was added dropwise $n$-butyl lithium (1.6 M solution in hexane, $5.5 \mathrm{~mL}, 8.742 \mathrm{mmol})$ at $-10{ }^{\circ} \mathrm{C}$. The reaction mixture was stirred at $-10{ }^{\circ} \mathrm{C}$ for an additional 30 min then gradually warmed to room temperature. The mixture was stirred for $2 \mathrm{~h}$, and albicanal $2(688 \mathrm{mg}, 3.112 \mathrm{mmol})$ in tetrahydrofuran $(15 \mathrm{~mL})$ was added at room temperature. After the mixture was stirred for $45 \mathrm{~min}$ at room temperature, a saturated aqueous $\mathrm{NH}_{4} \mathrm{Cl}$ solution was added. The resulting mixture was extracted with diethyl ether. The organic layers were combined, washed with brine, dried over $\mathrm{MgSO}_{4}$, filtered and concentrated in vacuo to give the crude products, which were purified by column chromatography on silica gel (from $0.5 \%$ to $20 \%$ ethyl acetate in hexane) resulting in alcohol $4(2.128 \mathrm{~g}, 77 \%)$ as a pale yellow solid: IR $\left(\mathrm{KBr}\right.$ disk, $\left.\mathrm{cm}^{-1}\right)$ 3594, 2930, 2866, 1466, 1211, 1161, 837; ${ }^{1} \mathrm{H}$ NMR $\left(\mathrm{CDCl}_{3}, 400 \mathrm{MHz}\right) \delta 6.23(\mathrm{~s}, 1 \mathrm{H})$, $5.22(\mathrm{dd}, J=6.4,4.6 \mathrm{~Hz}, 1 \mathrm{H}), 4.69(\mathrm{~s}, 1 \mathrm{H}), 4.62(\mathrm{~s}, 1 \mathrm{H}), 2.70(\mathrm{~d}, J=4.6 \mathrm{~Hz}, 1 \mathrm{H}), 2.47(\mathrm{~d}, J=6.1 \mathrm{~Hz}$ 1H), $2.37(\mathrm{~m}, 1 \mathrm{H}), 2.05-2.15(\mathrm{~m}, 1 \mathrm{H}), 1.90(\mathrm{~m}, 1 \mathrm{H}), 1.72(\mathrm{~m}, 2 \mathrm{H}), 1.61(\mathrm{~s}, 12 \mathrm{H}), 1.45(\mathrm{~m}, 1 \mathrm{H}), 1.42$ $(\mathrm{m}, 1 \mathrm{H}), 1.40(\mathrm{~m}, 2 \mathrm{H}), 1.30(\mathrm{~m}, 1 \mathrm{H}), 1.03(\mathrm{~s}, 3 \mathrm{H}), 1.00(\mathrm{~s}, 3 \mathrm{H}), 0.81(\mathrm{~s}, 3 \mathrm{H}),{ }^{13} \mathrm{C}$ NMR $\left(\mathrm{CDCl}_{3}, 100\right.$ MHz) $\delta 147.6,140.3,137.8,117.8,108.2,91.4,66.6,60.4,59.9,42.1,39.0,38.7,33.6,25.7,25.6$, 25.1, 24.7, 22.8, 22.3, 21.8, 19.3; ESI HRMS $m / z$ calcd for $\mathrm{C}_{27} \mathrm{H}_{38} \mathrm{O}_{5}[\mathrm{M}+\mathrm{Na}]^{+}$465.2617, found 
465.2615.

\section{Xanthate 5}

To a solution of alcohol $4(2.479 \mathrm{~g}, 5.601 \mathrm{mmol})$ in tetrahydrofuran $(28 \mathrm{~mL})$ was added dropwise sodium bis(tirmethylsily)amide (1.0 M solution in tetrahydrofuran, $16.8 \mathrm{~mL}, 16.803 \mathrm{mmol}$ ) at $-78{ }^{\circ} \mathrm{C}$. The reaction mixture was stirred for $30 \mathrm{~min}$ at $-78{ }^{\circ} \mathrm{C}$ and carbon disulfide $(2.36 \mathrm{~mL}$, $39.207 \mathrm{mmol}$ ) was added at the same temperature. The mixture was gradually warmed to $-40{ }^{\circ} \mathrm{C}$ for 1 $\mathrm{h}$, and then methyl iodide $(3.53 \mathrm{~mL}, 56.010 \mathrm{mmol})$ was added at $-78{ }^{\circ} \mathrm{C}$. After the mixture was gradually warmed to $0{ }^{\circ} \mathrm{C}$ for $2 \mathrm{~h}$, saturated aqueous $\mathrm{Na}_{2} \mathrm{SO}_{3}$ solution was added. The resulting mixture was extracted with ethyl acetate. The organic layers were combined, washed with brine, dried over $\mathrm{MgSO}_{4}$, filtered and concentrated in vacuo to give the crude xanthate 5, which was used without further purification.

\section{Acetonide 6}

To a solution of xanthate 5 in benzene $(50 \mathrm{~mL})$ was added tributyltin hydride $(6.7 \mathrm{~mL}$, $24.910 \mathrm{mmol})$ and 2,2 '-azobisisobutyronitrile $(82 \mathrm{mg}, 0.498 \mathrm{mmol})$ at room temperature. After the reaction mixture was stirred for $3 \mathrm{~h}$ under reflux conditions, the solution was cooled at room temperature. The solvent was removed in vacuo, yielding a crude product. Column chromatography on silica gel (from $0 \%$ to $3 \%$ ethyl acetate in hexane) yielded the corresponding acetonide 6 (2.807 g, $87 \%)$ as a white solid: IR (KBr disk, $\left.\mathrm{cm}^{-1}\right)$ 2936, 2866, 1719, 1647, 1462, 1211, 1161, 841; ${ }^{1} \mathrm{H}$ NMR $\left(\mathrm{CDCl}_{3}, 400 \mathrm{MHz}\right) \delta 6.14(\mathrm{~s}, 1 \mathrm{H}), 4.70(\mathrm{~s}, 1 \mathrm{H}), 4.69(\mathrm{~s}, 1 \mathrm{H}), 2.68(\mathrm{dd}, J=13.9,2.9 \mathrm{~Hz}, 2 \mathrm{H}), 2.51(\mathrm{~m}$, 2H), 2.31 (ddd, $J=13.9,4.2,2.4 \mathrm{~Hz}, 1 \mathrm{H}), 1.92(\mathrm{dt}, J=12.7,4.9 \mathrm{~Hz}, 1 \mathrm{H}), 1.79$ (br-d, $J=14.0 \mathrm{~Hz}, 1 \mathrm{H})$, $1.65-1.77(\mathrm{~m}, 2 \mathrm{H}), 1.61(\mathrm{~s}, 12 \mathrm{H}), 1.56(\mathrm{~d}, J=9.0 \mathrm{~Hz}, 2 \mathrm{H}), 1.50(\mathrm{dt}, J=14.0,3.6 \mathrm{~Hz}, 1 \mathrm{H}), 1.38(\mathrm{~m}$, 1H), $1.30(\mathrm{~m}, 1 \mathrm{H}), 1.25(\mathrm{~m}, 1 \mathrm{H}), 1.15(\mathrm{dd}, J=12.7,2.9 \mathrm{~Hz}, 1 \mathrm{H}), 0.86(\mathrm{~s}, 3 \mathrm{H}), 0.83(\mathrm{~s}, 3 \mathrm{H}), 0.77(\mathrm{~s}$, $3 \mathrm{H}) ;{ }^{13} \mathrm{C} \mathrm{NMR}\left(\mathrm{CDCl}_{3}, 100 \mathrm{MHz}\right) \delta 148.4,139.8,139.2,117.0,108.9,106.6,90.0,55.6,54.2,42.2$, 38.9, 38.9, 38.3, 33.6, 27.8, 26.8, 25.6, 24.5, 21.8, 19.5, 17.5, 14.1, 13.6; ESI HRMS m/z calcd for 
$\mathrm{C}_{27} \mathrm{H}_{38} \mathrm{O}_{4}[\mathrm{M}]^{+}$426.2770, found 426.2780 .

\section{Dihydroxyquinone 7}

To a solution of acetonide $6(20 \mu \mathrm{g}, 0.0469 \mathrm{mmol})$ in dichloromethane $(1.0 \mathrm{~mL})$ was added 1,3-propanedithiol $(24 \mu \mathrm{L}, 0.234 \mathrm{mmol})$ and trimethylsilyl trifluoromethanesulfonate ( $42 \mu \mathrm{L}, 0.234$ mmol) at $0{ }^{\circ} \mathrm{C}$. The reaction mixture was stirred for $5 \mathrm{~min}$ at $0{ }^{\circ} \mathrm{C}$, and tetrabutylammonium fluoride (1 $\mathrm{M}$ in tetrahydrofuran, $60 \mu \mathrm{L}, 0.0576 \mathrm{mmol}$ ) was added at the same temperature. After the mixture was stirred for $1 \mathrm{~min}$ at $0{ }^{\circ} \mathrm{C}, \mathrm{H}_{2} \mathrm{O}$ was added, and the resulting mixture was extracted with diethyl ether. The organic layers were combined, washed with brine, dried over $\mathrm{MgSO}_{4}$, filtered, and concentrated in vacuo yielding a crude product. Column chromatography on silica gel (50\% acetate in hexane) provided the corresponding dihydroxyquinone $7(14 \mathrm{mg}, 64 \%)$ as a pale yellow solid. Purification by preparative HPLC [column, Develosil C8-5 $(1.0 \times 25 \mathrm{~cm})$; mobile phase, acetonitrile; flow rate, 2.0 $\mathrm{ml} / \mathrm{min}$; UV detection, $210 \mathrm{~nm}$; retention time, $8 \mathrm{~min}$ ]: IR (KBr disk, $\left.\mathrm{cm}^{-1}\right)$ 3353, 2926, 2866, 1657, 1609, 1358, 1123, 965; ${ }^{1} \mathrm{H}$ NMR $\left(\mathrm{CDCl}_{3}, 400 \mathrm{MHz}\right) \delta 5.91(\mathrm{~s}, 1 \mathrm{H}), 2.51(\mathrm{dd}, J=17.8,4.6 \mathrm{~Hz}, 1 \mathrm{H})$, $2.22(\mathrm{~m}, 1 \mathrm{H}), 2.12(\mathrm{dd}, J=17.6,12.7 \mathrm{~Hz}, 1 \mathrm{H}), 1.81(\mathrm{~m}, 1 \mathrm{H}), 1.77(\mathrm{~m}, 1 \mathrm{H}), 1.62$ (ddt, $J=13.4,13.4$, $3.4 \mathrm{~Hz}, 1 \mathrm{H}), 1.47(\mathrm{~m}, 1 \mathrm{H}), 1.42(\mathrm{~m}, 1 \mathrm{H}), 1.25(\mathrm{~m}, 1 \mathrm{H}), 1.25(\mathrm{~s}, 3 \mathrm{H}), 1.20(\mathrm{~m}, 1 \mathrm{H}), 1.16(\mathrm{~m}, 1 \mathrm{H}), 0.97$ (m, 1H), $0.92(\mathrm{~m}, 1 \mathrm{H}), 0.90(\mathrm{~s}, 3 \mathrm{H}), 0.89(\mathrm{~s}, 3 \mathrm{H}), 0.84(\mathrm{~s}, 3 \mathrm{H}) ;{ }^{13} \mathrm{C} \mathrm{NMR}\left(\mathrm{CDCl}_{3}, 100 \mathrm{MHz}\right) \delta 182.3$, $182.2,155.2,154.5,114.0,104.7,82.7,55.9,51.1,41.6,40.0,39.2,37.1,33.3,33.2,21.5,20.6,19.7$, 18.4, 15.9, 15.0; ESI HRMS m/z calcd for $\mathrm{C}_{21} \mathrm{H}_{28} \mathrm{O}_{4}[\mathrm{M}-\mathrm{H}]^{-} 343.1908$, found 343.1900.

\section{Alcohol 8}

To a solution of acetonide $3(1.000 \mathrm{~g}, 4.580 \mathrm{mmol})$ in tetrahydrofuran $(23 \mathrm{~mL})$ was added dropwise $n$-butyl lithium (1.6 M solution in hexane, $3.9 \mathrm{~mL}, 6.299 \mathrm{mmol})$ at $-10{ }^{\circ} \mathrm{C}$. The reaction mixture was stirred for $30 \mathrm{~min}$ at $-10{ }^{\circ} \mathrm{C}$, and gradually warmed to room temperature. The mixture was stirred for $2 \mathrm{~h}$ at $-10{ }^{\circ} \mathrm{C}$, and cyclohexanecarboxaldehyde $(252 \mathrm{mg}, 2.250 \mathrm{mmol})$ in tetrahydrofuran $(11 \mathrm{~mL})$ was added at room temperature. After the mixture was stirred for $30 \mathrm{~min}$ at 
room temperature, a saturated aqueous $\mathrm{NH}_{4} \mathrm{Cl}$ solution was added, and the mixture was extracted with diethyl ether. The organic layers were combined, washed with brine, dried over $\mathrm{MgSO}_{4}$, filtered and concentrated in vacuo yielding a crude product. Column chromatography on silica gel (from $0.5 \%$ to $20 \%$ ethyl acetate in hexane) yielded alcohol 8 (698 $\mathrm{mg}, 93 \%)$ as a pale yellow solid: IR (KBr disk, $\left.\mathrm{cm}^{-1}\right) 3551,290,2851,1460,1161,839 ;{ }^{1} \mathrm{H} \mathrm{NMR}\left(\mathrm{CDCl}_{3}, 400 \mathrm{MHz}\right) \delta 6.24(\mathrm{~s}, 1 \mathrm{H}), 4.42(\mathrm{~m}, 1 \mathrm{H})$, $2.41(\mathrm{dd}, J=9.2,2.9 \mathrm{~Hz}, 1 \mathrm{H}), 2.40(\mathrm{~m}, 3 \mathrm{H}), 1.62-1.78(\mathrm{~m}, 1 \mathrm{H}), 1.62(\mathrm{~s}, 12 \mathrm{H}), 1.47-1.57(\mathrm{~m}, 1 \mathrm{H})$, 1.01-1.30 (m, 6H); ${ }^{13} \mathrm{C}$ NMR $\left(\mathrm{CDCl}_{3}, 100 \mathrm{MHz}\right) \delta$ 140.2, 137.9, 118.0, 91.5, 72.6, 44.2, 29.0, 26.4, 26.1, 25.8, 25.5; ESI HRMS $m / z$ calcd for $\mathrm{C}_{19} \mathrm{H}_{26} \mathrm{O}_{5}[\mathrm{M}+\mathrm{Na}]^{+} 357.1678$, found 357.1669.

\section{Xanthate 9}

To a solution of alcohol $8(218 \mathrm{mg}, 0.652 \mathrm{mmol})$ in tetrahydrofuran $(3.3 \mathrm{~mL})$ was added dropwise sodium bis(trimethylsily)amide $(1.0 \mathrm{M}$ solution in tetrahydrofuran, $2.0 \mathrm{~mL}, 1.957$ mmol) at $-78{ }^{\circ} \mathrm{C}$. The reaction mixture was stirred for 30 min at $-78{ }^{\circ} \mathrm{C}$ and carbon disulfide $(0.27$ $\mathrm{mL}, 4.564 \mathrm{mmol}$ ) was added at the same temperature. The mixture was gradually warmed to $-40{ }^{\circ} \mathrm{C}$ for $1 \mathrm{~h}$ and methyl iodide $(0.41 \mathrm{~mL}, 6.520 \mathrm{mmol})$ was added at $-78{ }^{\circ} \mathrm{C}$. After the mixture was gradually warmed to $0{ }^{\circ} \mathrm{C}$ for $2 \mathrm{~h}$, a saturated aqueous $\mathrm{Na}_{2} \mathrm{SO}_{3}$ solution was added. The resulting mixture was extracted with ethyl acetate. The organic layers were combined, washed with brine, dried over $\mathrm{MgSO}_{4}$, filtered and concentrated in vacuo to give the crude xanthate $\mathbf{9}$, which was used without further purification.

\section{Acetonide 10}

To a solution of xanthate $\mathbf{9}$ in toluene $(7.8 \mathrm{~mL})$ was added tributyltin hydride $(2.1$ $\mathrm{mL}, 7.843 \mathrm{mmol})$ and $2,2^{\prime}$-azobisisobutyronitrile $(13 \mathrm{mg}, 0.078 \mathrm{mmol})$ at room temperature. After the mixture was stirred for $1.5 \mathrm{~h}$ under reflux conditions, the solution was cooled at room temperature. The solvent was removed in vacuo, and the crude products were purified by column chromatography on silica gel (from $0 \%$ to 3\% ethyl acetate in hexane) yielding the corresponding acetonide $\mathbf{1 0}(207 \mathrm{mg}$, 
$100 \%)$ as a white solid: IR ( $\mathrm{KBr}$ disk, $\left.\mathrm{cm}^{-1}\right) 2957,2852,146,1203,841 ;{ }^{1} \mathrm{H} \mathrm{NMR}\left(\mathrm{CDCl}_{3}, 400 \mathrm{MHz}\right)$ $\delta 6.18(\mathrm{~s}, 1 \mathrm{H}), 2.38(\mathrm{~d}, J=7.7 \mathrm{~Hz}, 2 \mathrm{H}), 1.69(\mathrm{~m}, 3 \mathrm{H}), 1.62(\mathrm{~m}, 1 \mathrm{H}), 1.62(\mathrm{~s}, 12 \mathrm{H}), 1.45-1.60(\mathrm{~m}, 1 \mathrm{H})$, $1.33(\mathrm{~m}, 2 \mathrm{H}), 0.87-1.29(\mathrm{~m}, 5 \mathrm{H}) ;{ }^{13} \mathrm{C} \mathrm{NMR}\left(\mathrm{CDCl}_{3}, 100 \mathrm{MHz}\right) \delta 139.7,139.5,117.1,107.3,90.2$, 37.5, 32.9, 31.7, 26.5, 26.2, 25.5; ESI HRMS m/z calcd for $\mathrm{C}_{19} \mathrm{H}_{26} \mathrm{O}_{4}[\mathrm{M}]^{+}$318.1831, found 318.1831.

\section{Dihydroxyquinone 11}

To a solution of acetonide $10(20 \mathrm{mg}, 0.063 \mathrm{mmol})$ in 1,4-dioxane $(0.63 \mathrm{~mL})$ was added 1.0 $\mathrm{mL}$ aqueous $4 \mathrm{~N} \mathrm{HCl}$ solution at room temperature. After the reaction mixture was stirred for $5 \mathrm{~h}$ under reflux conditions, an aqueous $2 \mathrm{~N} \mathrm{NaOH}$ solution was added. The resulting mixture was extracted with chloroform. The organic layers were combined, washed with brine, dried over $\mathrm{MgSO}_{4}$, filtered and concentrated in vacuo yielding a crude product. Column chromatography on silica gel $(50 \%$ ethyl acetate in hexane) yielded dihydroxyquinone $11(11 \mathrm{mg}, 73 \%)$ as a pale yellow solid, which was further purified by preparative HPLC [column, Develosil C8-5 (2.0 x $25 \mathrm{~cm})$; mobile phase, acetonitrile; flow rate, $5.0 \mathrm{ml} / \mathrm{min}$; UV detection, $210 \mathrm{~nm}$; retention time, $10 \mathrm{~min}]$ : IR ( $\mathrm{KBr}$ disk, $\mathrm{cm}^{-1}$ ) 3308, 2922, 2853, 1644, 1618, 1231, 1184, 970; ${ }^{1} \mathrm{H}$ NMR $\left(\mathrm{CDCl}_{3}, 400 \mathrm{MHz}\right) \delta 7.71$ (br-s, 2H), 6.00 (s, $1 \mathrm{H}), 2.36(\mathrm{~d}, J=8.3 \mathrm{~Hz}, 2 \mathrm{H}), 1.50-1.74(\mathrm{~m}, 3 \mathrm{H}), 1.12-1.30(\mathrm{~m}, 4 \mathrm{H}), 0.92-1.20(\mathrm{~m}, 4 \mathrm{H}),{ }^{13} \mathrm{C}$ NMR $\left(\mathrm{CDCl}_{3}, 100 \mathrm{MHz}\right) \delta 115.7,102.1,37.0,33.2,30.0,26.3,26.1$; ESI HRMS $\mathrm{m} / \mathrm{z}$ calcd for $\mathrm{C}_{13} \mathrm{H}_{16} \mathrm{O}_{4}$ $[\mathrm{M}]^{+} 236.1049$, found 236.1047 .

\section{2. Plasmid construction and cell culture}

pcDNA3-FLAG epitope-tagged mCERK was prepared as described elsewhere (7), and pcDNA3-HA-tagged hSPHK1 and HA-tagged hSPHK2 were constructed as previously described (20). Human embryonic kidney (HEK) 293 cells and rat basophilic leukemia (RBL-2H3) cells were cultured as monolayers in Dulbecco's modified Eagle's medium and Eagle's minimum essential medium, respectively (both from Sigma, St Louis, MO, USA). Chinese hamster ovary (CHO-K1) cells 
were cultured in Ham's F-12 medium (Sigma). Media were supplemented with 10\% (v/v) fetal bovine serum (BioSource International, Camarillo, CA, USA), $100 \mathrm{U} / \mathrm{ml}$ penicillin and $100 \mu \mathrm{g} / \mathrm{ml}$ streptomycin (Sigma), and all cells were cultured at $37^{\circ} \mathrm{C}$ in a humidified atmosphere of $5 \%$ carbon dioxide. Transfections were performed using LIPOFECTAMINE-PLUS (Invitrogen, Carlsbad, CA, USA), according to the manufacturer's instructions. Plasmids used in the transfections were prepared with a Quantum Prep Plasmid Miniprep Kit (BIO-RAD, Hercules, CA, USA).

\section{3. In vitro ceramide kinase assay}

The activity of CERK was assayed as described by Bajjalieh et al. (8), with some modifications. Briefly, HEK 293 cells were transfected with pcDNA3-FLAG-mCERK and cultured for 24 hours. The cells were lysed in buffer (10 mM HEPES, 2 mM EGTA, $1 \mathrm{mM}$ dithiothreitol, 40 $\mathrm{mM} \mathrm{KCl}$, and Complete ${ }^{\mathrm{TM}}$ protease inhibitor mixture (Roche, Mannheim, Germany)). Cell lysates

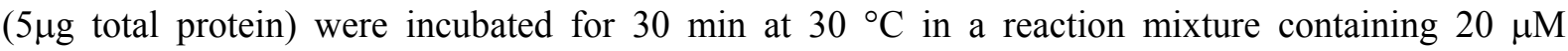
$\left[{ }^{32} \mathrm{P}\right] \mathrm{ATP}(10 \mathrm{mCi} / \mu \mathrm{mol}$, Perkin Elmer Life Science, Boston, MA) and $40 \mu \mathrm{M}$ ceramide (C18:0, d18:1, Sigma) in reaction buffer (20 mM HEPES, $80 \mathrm{mM} \mathrm{KCl,} 3 \mathrm{mM} \mathrm{CaCl} 2,1 \mathrm{mM}$ cardiolipin (Sigma), $1.5 \% \beta$-octyl glucoside, $0.2 \mathrm{mM}$ diethylenetriaminepentaacetic acid). Lipids were extracted and separated on Silica Gel 60 high performance TLC (HPTLC) plates (Merck, Darmstadt, Germany) using chloroform / acetone / methanol / acetic acid / water (10:4:3:2:1, v/v) as the solvent system. Bands were quantified using a Fujix Bio-Imaging Analyzer, BAS2500 (Fuji Photo Film, Tokyo, Japan).

\section{4. In vitro sphingosine kinase assay}

The kinase activity of SPHK was assayed as previously described (20). Briefly, lysates from CHO-K1 cells transfected with pcDNA3-HA-hSPHK1 or pcDNA3-HA-hSPHK2 were prepared as described for the ceramide kinase assay, and samples ( $1 \mu \mathrm{g}$ protein) from each lysate were incubated at $37^{\circ} \mathrm{C}$ for 30 min with $2 \mu \mathrm{Ci}\left[{ }^{32} \mathrm{P}\right] \mathrm{ATP}, 0.5 \mathrm{mM}$ cold ATP, and $40 \mu \mathrm{M}$ D-erythro-sphingosine (Sigma) 
in $200 \mu \mathrm{l}$ assay buffer $(20 \mathrm{mM}$ Tris- $\mathrm{HCl}(\mathrm{pH} 7.5), 0.25 \mathrm{mM}$ EDTA, $1 \mathrm{mM} \mathrm{MgCl}, 12 \mathrm{mM}$ $\beta$-glycerophosphate, $1 \mathrm{mM}$ sodium pyrophosphate, $5 \mathrm{mM} \mathrm{NaF}, 5 \mathrm{mM}$ sodium orthovanadate, $2 \mathrm{mM}$ dithiothreitol, and Complete ${ }^{\mathrm{TM}}$ protease inhibitor cocktail). For SphK2 assays, $200 \mathrm{M} \mathrm{KCl}$ was added in the assay buffer. Extracted lipids were separated by TLC with 1-butanol / acetic acid / water (3:1:1). S1P bands were visualized and quantified using a Fujix Bio-Imaging Analyzer, BAS2500.

\section{4. In vitro diacylglycerol kinase (DGK) assay}

The kinase activity of DGK was assayed as CERK assay with some modifications. Briefly, HEK 293 cells were transfected with p3xFLAG-CMV-human DGK $\gamma$ (a kind gift from Dr. Kanoh and Dr. Sakane, (21)) and cultured for 24 hours. The cells were lysed in buffer (10 mM HEPES, $2 \mathrm{mM}$ EGTA, $1 \mathrm{mM}$ dithiothreitol, $40 \mathrm{mM} \mathrm{KCl}$, and Complete ${ }^{\mathrm{TM}}$ protease inhibitor mixture (Roche, Mannheim, Germany)). Cell lysates $\left(2 \mu \mathrm{g}\right.$ total protein) were incubated for $5 \mathrm{~min}$ at $30{ }^{\circ} \mathrm{C}$ in a reaction mixture containing $10 \mu \mathrm{M}\left[{ }^{32} \mathrm{P}\right] \mathrm{ATP}(10 \mathrm{mCi} / \mu \mathrm{mol}$, Perkin Elmer Life Science, Boston, MA $)$, $500 \mu \mathrm{M}$ ATP (Roche) and $200 \mu \mathrm{M}$ diacylglycerol (Sigma) in reaction buffer (20 mM HEPES, $80 \mathrm{mM}$ $\mathrm{KCl}, 2 \mathrm{mM} \quad \mathrm{MgCl}_{2}, \quad 1 \mathrm{mM}$ cardiolipin (Sigma), $1.5 \% \quad \beta$-octyl glucoside, $0.2 \mathrm{mM}$ diethylenetriaminepentaacetic acid). Extracted lipids were separated by TLC with chloroform / acetone / methanol / acetic acid / water (10:4:3:2:1, v/v). PA bands were visualized and quantified using a Fujix Bio-Imaging Analyzer, BAS2500. DGK inihibitor (R59949) was purchased from Sigma.

\section{6. Metabolic labeling of cells and cellular studies}

RBL-2H3 cells $\left(1 \times 10^{7}\right.$ cells / $\left.\mathrm{ml}, 100 \mu \mathrm{l}\right)$ were incubated for $30 \mathrm{~min}$ at $37^{\circ} \mathrm{C}$ with $10 \mathrm{Ci}$ carrier-free $\left[{ }^{32} \mathrm{P}\right]$ orthophosphoric acid (PerkinElmer Life Sciences, 314-337 Tbq/ mmol, $5 \mathrm{mCi} / \mathrm{ml}$ ) in Dulbecco's modified eagle medium (high glucose, with L-glutamate, without sodium phosphate or sodium pyruvate) supplemented with $10 \%$ fetal bovine serum. After the incubation, vehicle or an 
analog of F-12509A was added and incubated for an additional 30 or $90 \mathrm{~min}$. Reactions were terminated by adding $700 \mu \mathrm{l}$ of chloroform / methanol (1:1). Next, $250 \mu \mathrm{l}$ of $1 \mathrm{M} \mathrm{KCl}$ were added, the mixture was vortexed for $5 \mathrm{~min}$ then centrifuged for $2 \mathrm{~min}$ at $12,000 \mathrm{X} \mathrm{g}$, and the upper phase was removed. Then, $45 \mu \mathrm{l}$ of $1 \mathrm{~N} \mathrm{NaOH} /$ methanol and $75 \mu \mathrm{l}$ of chloroform / methanol (1:1) were added, and the mixture was incubated at $50{ }^{\circ} \mathrm{C}$ for $50 \mathrm{~min}$. After the incubation, $55 \mu \mathrm{l}$ of $1 \mathrm{~N} \mathrm{HCl} /$ methanol and $75 \mu \mathrm{l}$ of $1 \mathrm{M} \mathrm{KCl}$ were added, and the mixture was vortexed vigorously and centrifuged at 12,000 $\mathrm{X} g$ for 2 min. After centrifugation, the upper phase was removed, and the liquid was evaporated. $\left[{ }^{32} \mathrm{P}\right] \mathrm{C} 1 \mathrm{P}$ was detected by HPTLC using the same method as described above.

\section{7. Cytotoxicity assay}

Cytotoxicity was evaluated by measuring the mitochondrial dehydrogenase enzymatic activity in cells using 2-(2-methoxy-4-nitrophenyl)-3-(4-nitrophenyl)-5-(2,4-disulfophenyl)-2H-tetrasolium (cell counting kit-8, Dojindo, Japan). RBL-2H3 cells $\left(5 \times 10^{3}\right.$ cells / $100 \mu$ l) were plated in 96-well dishes and incubated at $37{ }^{\circ} \mathrm{C}$ for $24 \mathrm{hrs}$ in a humidified atmosphere of $5 \% \mathrm{CO}_{2}$. Cells were incubated with CERK inhibitor (K1) for an additional 24 to $48 \mathrm{hrs}$. Next, $10 \mu \mathrm{l}$ of cell counting kit- 8 was added to each well, and the cells were incubated for another 4 hrs. The absorbance of light at a wavelength of $450 \mathrm{~nm}$ was measured in each well by a densitometer (CS-9300PC, Shimazu, Kyoto, Japan).

\section{8. Degranulation assays}

Rat basophilic leukemia (RBL-2H3) cells were cultured as described above, centrifuged, washed, then resuspended in Tyrode's buffer (25 mM PIPES (pH 7.2), $119 \mathrm{mM} \mathrm{NaCl}, 5 \mathrm{mM} \mathrm{KCl}, 0.4$ $\mathrm{mM} \mathrm{MgSO}_{4}, 5.6 \mathrm{mM}$ glucose, $1 \mathrm{mM} \mathrm{CaCl}_{2}$, and $0.1 \%$ bovine serum albumin (BSA, Sigma)). For $\mathrm{Ca}^{2+}$ ionophore stimulation, cells $\left(1 \times 10^{7} \mathrm{cell} / \mathrm{ml}, 100 \mu \mathrm{l}\right)$ were pre-incubated with the CERK inhibitor (K1) for 10 min at $37^{\circ} \mathrm{C}$, then incubated with A23187 (final concentration $1 \mu \mathrm{M}$, Sigma) for 40 min at $37^{\circ} \mathrm{C}$. For IgE/antigen stimulation, cells were incubated at room temperature for $30 \mathrm{~min}$ in $10 \mu \mathrm{g} / \mathrm{ml}$ 
anti-DNP IgE (a kind gift from Dr. Yamashita (22)), washed, incubated with inhibitors for $10 \mathrm{~min}$ at $37{ }^{\circ} \mathrm{C}$, then stimulated with $1 \mu \mathrm{g} / \mathrm{ml}$ DNP-BSA for $40 \mathrm{~min}$ at $37^{\circ} \mathrm{C}$. After the applicable stimulation, all cells were centrifuged at $14,000 \mathrm{Xg}$ for $5 \mathrm{~min}$, and the $\beta$-hexosaminidase activity was measured in both the supernatant and cell pellet, as described previously (21).

\section{9. Western blot analysis}

IgE/antigen stimulation was performed as described above, then cells were lysed with lysis buffer (62.5 mMTris- $\mathrm{HCl}(\mathrm{pH}$ 6.8), 2\% (w/v) SDS, 10\% (v/v) glycerol, 5\% (w/v) 2-mercaptoethanol, $5 \mathrm{mM}$ sodium orthovanadate, $5 \mathrm{mM}$ EDTA, $5 \mathrm{mM} \mathrm{NaF}$ and Complete ${ }^{\mathrm{TM}}$ protease inhibitor). The proteins were separated by SDS-PAGE and transferred to a PVDF membrane (Millipore, Bedford, MA, USA). After blocking with 5\% (w/v) BSA in TBST (20 mM Tris- $\mathrm{HCl}(\mathrm{pH} 7.5), 137 \mathrm{mM} \mathrm{NaCl}$ and $0.05 \%(\mathrm{v} / \mathrm{v})$ Tween 20$)$, the blot was incubated overnight at $4{ }^{\circ} \mathrm{C}$ with an anti-phosphotyrosine antibody (PY-20) (Transduction Laboratories, Lexington, KY) or an anti- $\gamma$-tubulin monoclonal antibody (GTU-88, Sigma), each diluted 1:1000 in TBST containing 5\% BSA. After four washes in TBST, the blot was incubated for $30 \mathrm{~min}$ at room temperature with horseradish-peroxidase-conjugated anti-mouse IgG-F(ab')2 fragment (Amersham Biosciences, Piscataway, NJ, USA) diluted 1:10,000 in TBST, and washed as above. Immunoreactive bands were visualized by ECL plus detection kits (Amersham Biosciences).

\section{10. Intracellular $\mathrm{Ca}^{2+}$ measurement}

RBL cells were incubated for $30 \mathrm{~min}$ at room temperature with anti-DNP $\operatorname{IgE}(10 \mu \mathrm{g} / \mathrm{ml})$ in Tyrode's buffer then washed with Tyrode's buffer. Subsequently, the cells were loaded with $1 \mu \mathrm{M}$ Fura-2/AM for $15 \mathrm{~min}$ at room temperature, and treated with the inhibitor for an additional $10 \mathrm{~min}$ at

$37^{\circ} \mathrm{C}$. The cells were washed twice with Tyrode's buffer, and antigen stimulation was performed as described above. The fluorescence intencity in cells was measured with a fluorescence spectrometer (CAF-100/ Jasco, Tokyo, Japan) at excitation wavelength of 340 or $380 \mathrm{~nm}$ and emission wavelength 
of $500 \mathrm{~nm}$. Intensities were monitored and stored by Power Lab (ADInstruments, Castle Hill, Australia) running Chart software v4.0 (ADInstruments, Mountain View CA, USA). All data were analyzed with Chart software v4.0.

\section{11. Statistical analysis}

The significance of differences was determined by Student's $t$ test. Values were considered significant at $\mathrm{P}<0.05$

\section{Results}

\section{1. Synthesis of F-12509A analogs}

We recently synthesized a novel sphingosine kinase inhibitor, F-12509A (Scheme 1; compound 8), which was isolated from microbial metabolites (23). In the course of that study, we synthesized an olefin regioisomer of F-12509A by reacting dl-arbicanal (compound 2) (24), derived from dl-arbicanol (Compound 1) (24), with a lithium anion generated from acetonide (compound 3) (26) to produce the adduct (compound 4), with a $77 \%$ yield. This compound (compound 4) was transformed into the corresponding xanthate (compound 5), which was treated with tributyltin hydride (27) in the presence of $2,2^{\prime}$-azobisisobutyronitrile to produce compound 6 in an $87 \%$ yield. Removal of the bisacetonide was successfully accomplished by the modification procedure of Snider's method (28). Compound 7 (K1) was treated with trimethylsilyl trifluoromethanesulfonate in the presence of 1,3-propanedithiol, followed by treatment with tetrabutylammonium fluoride to produce compound 7 , whose double bond is at the end position, in a 64\% yield. Natural F-12509A (compound 8) and its enantiomer were synthesized by a similar method.

Cyclohexane derivative 11 (K2) was synthesized according to the procedure used for the F-12509A olefin isomer 7 (Scheme 2). Reacting cyclohexanecarboxaldehyde with the anione derived from the acetonide 3 gave adduct 8 in a 93\% yield. After the obtained compound 8 was transformed 
into the corresponding xanthate 9 , this group was reductively removed by a radical reaction to obtain compound 10 in quantity. Treatment of compound 10 with acid produced the desired product 11 in a $73 \%$ yield. We have named compounds 7 and $11, \mathrm{~K} 1$ and $\mathrm{K} 2$, respectively.

\section{2. K1 inhibits CERK activity in vitro}

To determine whether F-12509A analogs are inhibitors of CERK activity, we first examined their effects in vitro. Of the analogs tested, K1 most effectively inhibited the CERK activity (Fig.1A). Consistent with a previous report (13), F-12509A exhibited modest inhibitory effects on CERK activity at high concentrations. In contrast, $\mathrm{K} 1$ showed a much stronger inhibitory effect than either F-12509A or K2 did (Fig.1A). Since F-12509A was initially reported as a novel SPHK inhibitor, we also examined the inhibitory effect of K1 on SPHK1 and SPHK2, but surprisingly, found almost no inhibitory effect. We next examined effects of K1 on human DGK. As a result, a well konwn DGK inhibitor, R59949, inhibited DGK $\gamma$ activity to $55 \%$ even at $10 \mu \mathrm{M}$ (data not shown), but $\mathrm{K} 1$ had almost no inhibitory effect on DGK $\gamma$ activity (Supplementary Figure 1). Together, these data suggest that K1 has a specific inhibitory effect for CERK activity (Fig.1B).

\section{3. $\mathrm{K} 1$ is membrane permeable and an effective CERK inhibitor in intact cells}

To determine whether $\mathrm{K} 1$ can also inhibit CERK in intact cells, we examined the amount of $\mathrm{C} 1 \mathrm{P}$ in RBL-2H3 cells grown in the presence of the analog. The cells were labeled with $\left[{ }^{32} \mathrm{P}\right]$ orthophosphoric acid, and incubated in the absence or presence of K1. In treated cells, the amount of

$\left[{ }^{32} \mathrm{P}\right] \mathrm{C} 1 \mathrm{P}$ decreased over time to $40 \%$ compared untreated cells (Fig.2), indicating that $\mathrm{K} 1$ is membrane permeable and effective in intact cells. Unexpectedly, $100 \mu \mathrm{M} \mathrm{K} 1$ was not significantly more effective than $50 \mu \mathrm{M} \mathrm{K} 1$, suggesting that $50 \mu \mathrm{M}$ is sufficient for maximum inhibition. Therefore, we set $100 \mu \mathrm{M}$ as the maximum concentration used for further experiments.

\section{4. K1 has no cytotoxic effect on RBL-2H3 cells}


C2-ceramide and the common SPHK inhibitor N,N-dimethylsphingosine are both highly cytotoxic, so we also examined the cytotoxicity of K1. RBL-2H3 cells were incubated with K1 for 24 hours, and the cell viability was analyzed by measuring the mitochondrial dehydrogenase activity. Interestingly, even at $100 \mu \mathrm{M}, \mathrm{K} 1$ did not affect the growth of RBL-2H3 cells (Fig.3). This result clearly demonstrates that K1has no cytotoxicity.

\section{5. Suppression of mast cell degranulation by K1}

In a previous study, we demonstrated that CERK is involved in calcium ionophore-induced mast cell degranulation. Here, we analyzed the effect of $\mathrm{K} 1$ on calcium ionophore-induced deregulation in RBL-2H3 cells by measuring the release of $\beta$-hexosaminidase. K1 inhibited the induced $\beta$-hexosaminidase release, in a dose dependent manner (Fig.4A). Approximately 50\% inhibition was achieved at a concentration of $100 \mu \mathrm{M} \mathrm{K} 1$. Additionally, even at $100 \mu \mathrm{M}, \mathrm{K} 1 \mathrm{did}$ not affect baseline values of $\beta$-hexosaminidase release, suggesting that its inhibitory effect was limited to the calcium ionophore-induced release (Fig.4A). In RBL-2H3 cells, calcium ionophore alone can induce mast cell degranulation, indicating that $\mathrm{Ca}^{2+}$ elevation can mediate all the required steps (29).

Similar downstream signaling leads to granule fusion and exocytosis in IgE/antigen-induced degranulation (7). Therefore, we next examined the effect of $\mathrm{K} 1$ on IgE/antigen-induced mast cell degranulation. IgE/antigen-induced degranulation was suppressed by K1, with similar dose dependency and suppression efficacy as those observed for the calcium ionophore-induced degranulation (Fig.4B). Inhibition of the calcium ionophore- or IgE/antigen-induced degranulation by a CERK inhibitor provides further evidence that CERK mediates the downstream signaling of $\mathrm{Ca}^{2+}$.

3. 6. K1 has no discernible effect on IgE/antigen-induced global tyrosine phosphorylation and $\mathrm{Ca}^{2+}$ elevation

To determine whether $\mathrm{K} 1$ intervenes in the initial steps of IgE/antigen-induced degranulation pathways, we examined its effect on the global tyrosine phosphorylation and $\mathrm{Ca}^{2+}$ elevation triggered 
by FceRỊcross-linking. Western blot analysis using an anti-phosphotyrosine antibody (PY-20) indicated that IgE/antigen induced-tyrosine phosphorylation was not affected by $100 \mu \mathrm{M} \mathrm{K} 1$ treatment (Fig.5A). This result rules out the possibility that $\mathrm{K} 1$ treatment suppresses mast cell degranulation by inhibiting the tyrosine phosphorylation of signaling molecules. We next examined IgE/antigen-induced $\mathrm{Ca}^{2+}$ mobilization using Fura-2/AM. There was no significant difference between the K1-treated cells and control cells (vehicle-treated) (Fig.5B), indicating that $\mathrm{K} 1$ treatment does not affect the signaling pathways from FceRI to $\mathrm{Ca}^{2+}$ mobilization. In conclusion, the absence of any detectable effect by $\mathrm{K} 1$ on tyrosine phosphorylation or $\mathrm{Ca}^{2+}$ mobilization suggests that has no side effect on the initial steps in FceRI signaling, and that it specifically inhibits the downstream signaling following $\mathrm{IgE} /$ antigen-induced $\mathrm{Ca}^{2+}$ mobilization.

\section{Discussion}

We report here on the synthesis of a CERK inhibitor capable of preventing mast cell degranulation. Although being an olefin isomer of the SPHK inhibitor F12509A, K1 specifically inhibited CERK in vitro without inhibiting SPHKs and DGK $\gamma$ (Fig.1B and Supplementary Figure 1). Furthermore, since SPHK inhibition prevents IgE/antigen-induced $\mathrm{Ca}^{2+}$ mobilization (30-32), the absence of similar inhibition by K1 (Fig.5B) rules out the possibility that K1 suppresses mast cell degranulation by inhibiting SPHK activity. Although both SPHK and CERK are known to be involved in mast cell degranulation, these results suggest these kinases mediate distinct pathways in FceRI signaling.

Treatment of RBL-2H3 cells with $100 \mu \mathrm{M} \mathrm{K} 1$ reduced C1P levels to 40\% (Fig.2), and K1 suppressed mast cell degranulation to a similar extent (Fig.4 A, B). Collectively, these results imply a relationship between intracellular C1P levels and degranulation. Relative to its effects in vitro (Fig.2), K1 exhibited less inhibition in living cells (Fig.2). This may be due to the low membrane permeability of K1. Future studies to modify the K1 structure to design improved CERK inhibitors with greater 
efficacy in living cells will be of great interest.

Previous studies have used C2-ceramide to inhibit CERK activity. However, C2-ceramide is highly cytotoxic and exhibits broad specificity (14-17). In contrast, K1 has advantages not only in its selectivity but also in being nontoxic (Fig.3), making K1 a more useful and accurate tool than currently available compounds in identifying roles for CERK.

Several protein-tyrosine kinase (PTK) inhibitors have been reported to inhibit mast cell activation. For instance, ER-27319 and terreic acid inhibit IgE/antigen-induced mast cell activation by specifically inhibiting Syk and Btk, respectively $(33,34)$. However, PTK inhibitors target molecules involved in early signaling events following antigen stimulation, and some are cytotoxic because of the multiple roles of PTKs in cellular signaling. Thus, targeting not only the molecules in the signaling pathways initiated by FceRI cross-linking but also molecules required for granule fusion and exocytosis, provides a rational strategy for anti-allergy therapeutics (35). Thus, inhibition of CERK may be a novel approach to inhibiting mast cell degranulation by regulating granule fusion and exocytosis. Accumulating evidence implicates CERK as a novel regulator of granule to plasma membrane fusion (7-10), although the molecular mechanisms involved in the regulation of granule fusion and exocytosis by CERK and C1P have yet to be investigated. K1 may prove to be a useful tool for studying such biological functions of CERK and C1P. Additionally, our identification and characterization of the novel CERK inhibitor K1 demonstrates the therapeutic potential of CERK inhibitors in the treatment of allergic diseases.

\section{Acknowledgements}

This work was supported in part by a Grant-in-Aid for Scientific Research on Priority Areas (B) (12140201) from the Ministry of Education, Culture, Sports, Science and Technology of Japan. We thank Dr. Kanoh and Dr. Sakane (Sapporo Medical University, Japan) for providing DGK constructs. 


\section{Notes}

${ }^{1}$ These authors contributed equally to this work.

Abbreviations: CERK, ceramide kinase; C1P, ceramide 1-phosphate; SM, sphingomyelin; CER, ceramide; SPH, sphingosine; S1P, sphingosine 1-phosphate; SPHK, sphingosine kinase; PLD, phospholipase D; PTK, protein-tyrosine kinase

\section{References}

[1] H. Metzger, G. Alcaraz, R. Hohman, J.P. Kinet, V. Pribluda and R. Quarto, The receptor with high affinity for immunoglobulin E, Annu. Rev. Immunol. 4 (1986), pp. 419-470.

[2] J.P. Kinet, The high-affinity IgE receptor ( $\mathrm{Fc}$ epsilon RI): from physiology to pathology, Annu. Rev. Immunol. 17 (1999), pp. 931-972.

[3] S. Spiegel and A.H. Merrill, Jr., Sphingolipid metabolism and cell growth regulation, FASEB J. 10 (1996), pp. 1388-1397.

[4] Y. Igarashi, Functional roles of sphingosine, sphingosine 1-phosphate, and methylsphingosines: in regard to membrane sphingolipid signaling pathways, J. Biochem. (Tokyo) 122 (1997), pp. 1080-1087. [5] D.K. Perry and Y.A. Hannun, The role of ceramide in cell signaling, Biochim. Biophys. Acta. 1436 (1998), pp. 233-243.

[6] A. Olivera and J. Rivera, Sphingolipids and the balancing of immune cell function: lessons from the mast cell, J. Immunol. 174 (2005), pp. 1153-1158.

[7] S. Mitsutake, T.J. Kim, Y. Inagaki, M. Kato, T. Yamashita and Y. Igarashi, Ceramide kinase is a mediator of calcium-dependent degranulation in mast cells, J. Biol. Chem. 279 (2004), pp. $17570-17577$.

[8] T. Baumruker, F. Bornancin and A. Billich, The role of sphingosine and ceramide kinases in 
inflammatory responses, Immunol. Lett. 96 (2005), pp. 175-185.

[9] S.M. Bajjalieh, T.F. Martin and E. Floor, Synaptic vesicle ceramide kinase. A calcium-stimulated lipid kinase that co-purifies with brain synaptic vesicles, J. Biol. Chem. 264 (1989), pp. 14354-14360.

[10] V.T. Hinkovska-Galcheva, L.A. Boxer, P.J. Mansfield, D. Harsh, A. Blackwood and J.A. Shayman, The formation of ceramide-1-phosphate during neutrophil phagocytosis and its role in liposome fusion, J. Biol. Chem. 273 (1998), pp. 33203-33209.

[11] V. Hinkovska-Galcheva, L.A. Boxer, A. Kindzelskii, M. Hiraoka, A. Abe, S. Goparju, S. Spiegel, H.R. Petty and J.A. Shayman, Ceramide 1-phosphate, a mediator of phagocytosis, J. Biol. Chem. 280 (2005), pp. 26612-26621.

[12] B.J. Pettus, A. Bielawska, P. Subramanian, D.S. Wijesinghe, M. Maceyka, C.C. Leslie, J.H. Evans, J. Freiberg, P. Roddy, Y.A. Hannun and C.E. Chalfant, Ceramide 1-phosphate is a direct activator of cytosolic phospholipase A2, J. Biol. Chem. 279 (2004), pp. 11320-11326.

[13] M. Sugiura, K. Kono, H. Liu, T. Shimizugawa, H. Minekura, S. Spiegel and T. Kohama, Ceramide kinase, a novel lipid kinase. Molecular cloning and functional characterization, J. Biol. Chem. 277 (2002), pp. 23294-23300.

[14] S. Mitsutake and Y. Igarashi, Calmodulin is involved in the Ca2+-dependent activation of ceramide kinase as a calcium-sensor, J. Biol. Chem. in press (M501962200).

[15] S.J. Suchard, V. Hinkovska-Galcheva, P.J. Mansfield, L.A. Boxer and J.A. Shayman, Ceramide inhibits IgG-dependent phagocytosis in human polymorphonuclear leukocytes, Blood 89 (1997), pp. $2139-2147$.

[16] Y. Nakamura, S. Nakashima, K. Ojio, Y. Banno, H. Miyata and Y. Nozawa, Ceramide inhibits IgE-mediated activation of phospholipase $\mathrm{D}$, but not of phospholipase $\mathrm{C}$, in rat basophilic leukemia (RBL-2H3) cells, J. Immunol. 156 (1996), pp. 256-262.

[17] A. Abousalham, C. Liossis, L. O'Brien and D.N. Brindley, Cell-permeable Ceramides Prevent the Activation of Phospholipase D by ADP-ribosylation Factor and RhoA, J. Biol. Chem. 272 (1997), pp. 1069-1075. 
[18] L.M. Obeid, C.M. Linardic, L.A. Karolak and Y.A. Hannun, Programmed cell death induced by ceramide, Science 259 (1993), pp. 1769-1771.

[19] K. Kono, M. Sugiura and T. Kohama, Inhibition of recombinant sphingosine kinases by novel inhibitors of microbial origin, F-12509A and B-5354c, J. Antibiot. (Tokyo) 55 (2002), pp. 99-103. [20] J.W. Kim, Y.W. Kim, Y. Inagaki, Y.A. Hwang, S. Mitsutake, Y.W. Ryu, W.K. Lee, H.J. Ha, C.S. Park and Y. Igarashi, Synthesis and evaluation of sphingoid analogs as inhibitors of sphingosine kinases, Bioorg. Med. Chem. 13 (2005), pp. 3475-3485.

[21] S. Tsushima, M. Kai, K. Yamada, S. Imai, K. Houkin, H. Kanoh, and F. Sakane, Diacylglycerol Kinase Serves as an Upstream Suppressor of Rac1 and Lamellipodium Formation, J. Biol. Chem. 279 (2004), pp. 28603-28613.

[22] T. Yamashita, T. Yamaguchi, K. Murakami and S. Nagasawa, Detergent-resistant membrane domains are required for mast cell activation but dispensable for tyrosine phosphorylation upon aggregation of the high affinity receptor for IgE, J. Biochem. (Tokyo) 129 (2001), pp. 861-868. [23] K. Kono, M. Tanaka, T. Ogita, T. Hosoya and T. Kohama, F-12509A, a new sphingosine kinase inhibitor, produced by a discomycete, J. Antibiot. (Tokyo) 53 (2000), pp. 459-466.

[24] S. Poigny, T. Huor, M. Guyot, and M. Samadi, Synthesis of (-)-Hyatellaquinone and Revision of Absolute Configuration of Naturally Occurring (+)-Hyatellaquinone J. Org. Chem. 64 (1999) pp. 9318-9320.

[25] N. Furuichi, T.Hata, H. Soetjipto, M. Kato, and S. Katsumura, Common synthetic strategy for optically active cyclic terpenoids having a 1,1,5-trimethyl-trans-decalin nucleus: syntheses of (+)-acuminolide, (-)-spongianolide A, and (+)-scalarenedial Tetrahedron 57 (2001), pp. 8425-8442.

[26] T.J. Reddy, T. Iwama, H.J. Halpern and V.H. Rawal, General synthesis of persistent trityl radicals for EPR imaging of biological systems, J. Org. Chem. 67 (2002), pp. 4635-4639.

[27] D.H.R. Barton, and W.B. Motherwell, New and selective reactions and reagents in carbohydrate chemistry. Pure \& Appl. Chem. 53 (1981), pp. 15 and references cited therein.

[28] Y. Gu, and B.B. Snider, Synthesis of ent-haterumalide NA (ent-oocydin A) methyl ester, Org. Lett. 
5 (2003), pp. 4385-4388.

[29] T.N. Lo, W. Saul and M.A. Beaven, The actions of Ca2+ ionophores on rat basophilic (2H3) cells are dependent on cellular ATP and hydrolysis of inositol phospholipids: A comparison with antigen stimulation, J. Biol. Chem. 262 (1987), pp. 4141-4145.

[30] O.H. Choi, J.H. Kim and J.P. Kinet, Calcium mobilization via sphingosine kinase in signalling by the Fc epsilon RI antigen receptor, Nature 380 (1996), pp. 634-636.

[31] A. Melendez, R.A. Floto, D.J. Gillooly, M.M. Harnett and J.M. Allen, FcgammaRI coupling to phospholipase D initiates sphingosine kinase-mediated calcium mobilization and vesicular trafficking, J. Biol. Chem. 273 (1998), pp. 9393-9402.

[32] A.J. Melendez and A.K. Khaw, Dichotomy of $\mathrm{Ca} 2+$ signals triggered by different phospholipid pathways in antigen stimulation of human mast cells, J. Biol. Chem. 277 (2002), pp. 17255-17262. [33] K. Moriya, J. Rivera, S. Odom, Y. Sakuma, K. Muramato, T. Yoshiuchi, M. Miyamoto and K. Yamada, ER-27319, an acridone-related compound, inhibits release of antigen-induced allergic mediators from mast cells by selective inhibition of fcepsilon receptor I-mediated activation of Syk, Proc. Natl. Acad. Sci. U. S. A. 94 (1997), pp. 12539-12544.

[34] Y. Kawakami, S.E. Hartman, E. Kinoshita, H. Suzuki, J. Kitaura, L. Yao, N. Inagaki, A. Franco, D. Hata, M. Maeda-Yamamoto, H. Fukamachi, H. Nagai and T. Kawakami, Terreic acid, a quinone epoxide inhibitor of Bruton's tyrosine kinase, Proc. Natl. Acad. Sci. U. S. A. 96 (1999), pp. 2227-2232. [35] M. Kovarova and J. Rivera, A molecular understanding of mast cell activation and the promise of anti-allergic therapeutics, Curr. Med. Chem. 11 (2004), pp. 2083-2091. 


\section{Figures}

\section{Scheme 1}<smiles>C=C1CCC2C(C)CCCC2(C)C1CO</smiles>

1

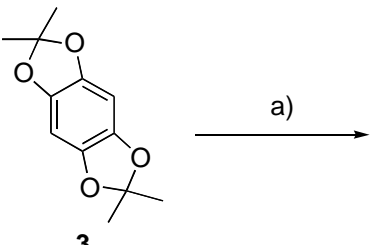

ref 22<smiles>C=C1CC[C@H]2C(C)(C)CCC[C@]2(C)[C@H]1C=O</smiles>

2

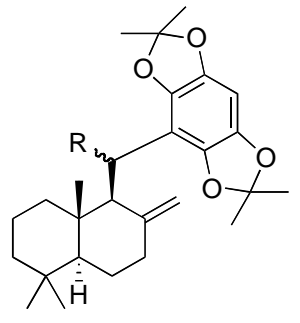

4: $\mathrm{R}=\mathrm{OH}$

$$
\begin{gathered}
\text { 4: } \mathrm{R}=\mathrm{OH} \longrightarrow \mathrm{b}) \\
\text { 5: R= OC(S)SMe } \\
6: \mathrm{R}=\mathrm{H}
\end{gathered}
$$<smiles>CC1(C)CCCC2(C)C(CC3=C(O)C(=O)C=C(O)C3=O)CCC(=O)C12</smiles>

8: F-12509A

a) $n$-BuLi, THF, $-10^{\circ} \mathrm{C}$ to rt; then albicanal 2 , THF, $-10^{\circ} \mathrm{C}$ to rt, $77 \%$;

b) NaHMDS, THF, $-78^{\circ} \mathrm{C}$; $\mathrm{CS}_{2},-78^{\circ} \mathrm{C}$ to $-55^{\circ} \mathrm{C}$; then Mel, $-78^{\circ} \mathrm{C}$ to $0^{\circ} \mathrm{C}$;

c) $n-\mathrm{Bu}_{3} \mathrm{SnH}, \mathrm{AIBN}, \mathrm{PhH}$, rt to reflux, $87 \%$ for 2 steps;

d) TMSOTf, 1,3-propanedithiol, $0{ }^{\circ} \mathrm{C}$; then TBAF, $0{ }^{\circ} \mathrm{C}, 64 \%$

\section{Scheme 2}<smiles>CC1(C)Oc2cc3c(cc2O1)OC(C)(C)O3</smiles>

3

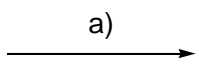<smiles>[R]C(c1c2c(cc3c1OC(C)(C)O3)OC(C)(C)O2)C1CCCCC1</smiles>

$\mathrm{R}=\mathrm{OH}: \mathbf{8}$

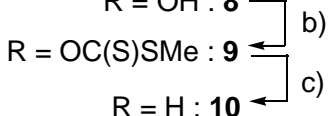

d)<smiles>O=C1C=C(O)C(=O)C(CC2CCCCC2)=C1O</smiles>

11: K2

a) $n$-BuLi, THF, $-10{ }^{\circ} \mathrm{C}$ to rt; then cyclohexanecarboxaldehyde, THF, $-10{ }^{\circ} \mathrm{C}$ to rt, $93 \%$;

b) NaHMDS, THF, $-78^{\circ} \mathrm{C}$; $\mathrm{CS}_{2},-78^{\circ} \mathrm{C}$ to $-55^{\circ} \mathrm{C}$; then Mel, $-78^{\circ} \mathrm{C}$ to $0^{\circ} \mathrm{C}$;

c) $n-\mathrm{Bu}_{3} \mathrm{SnH}, \mathrm{AlBN}, \mathrm{PhH}$, rt to reflux, quant. for 2 steps;

d) $4 \mathrm{~N} \mathrm{HCl}$, air, 1,4-dioxane, reflux, $73 \%$ 
Fig. 1A

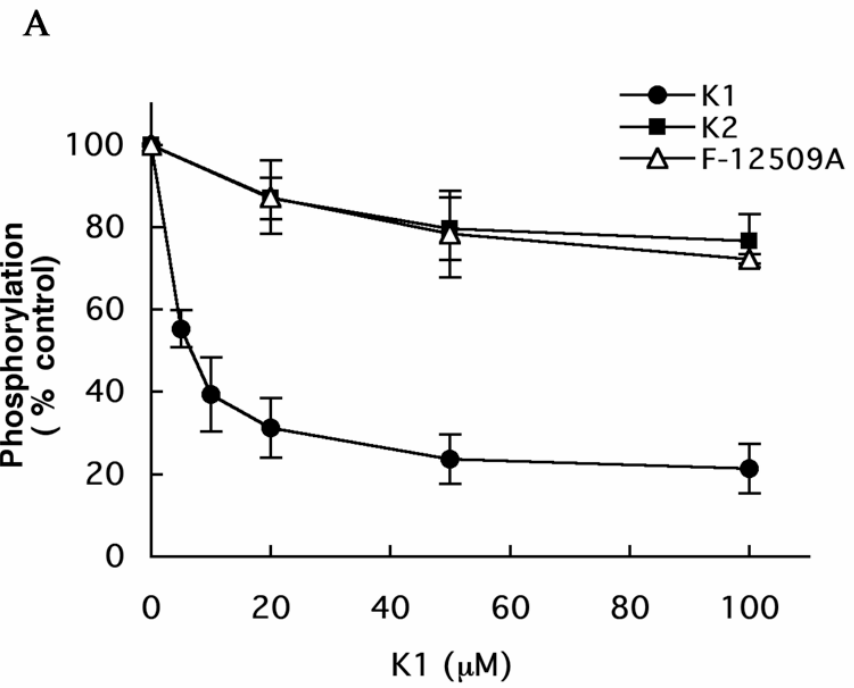

Fig.1B

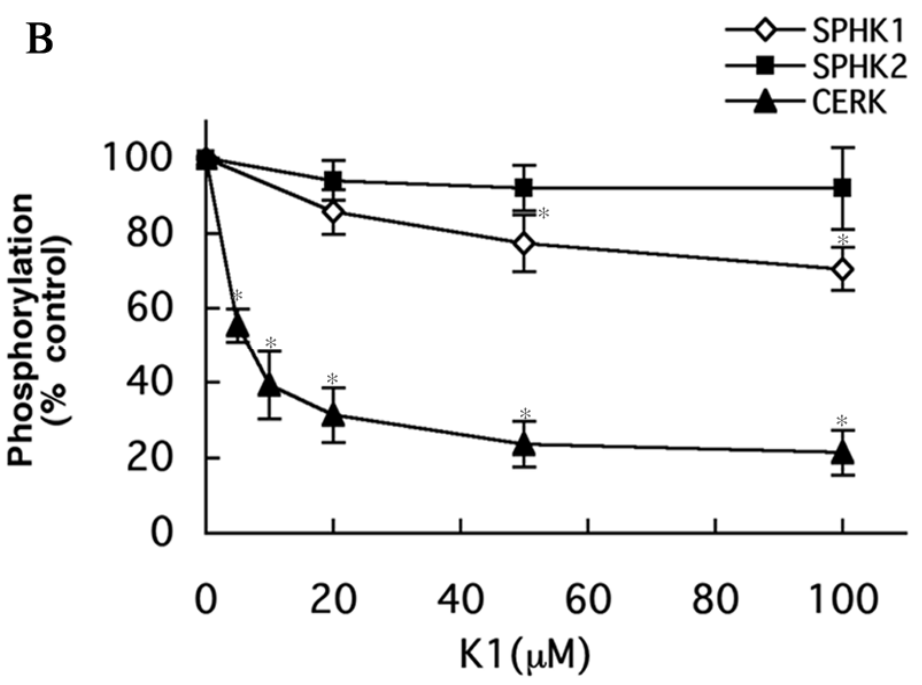


Fig.2

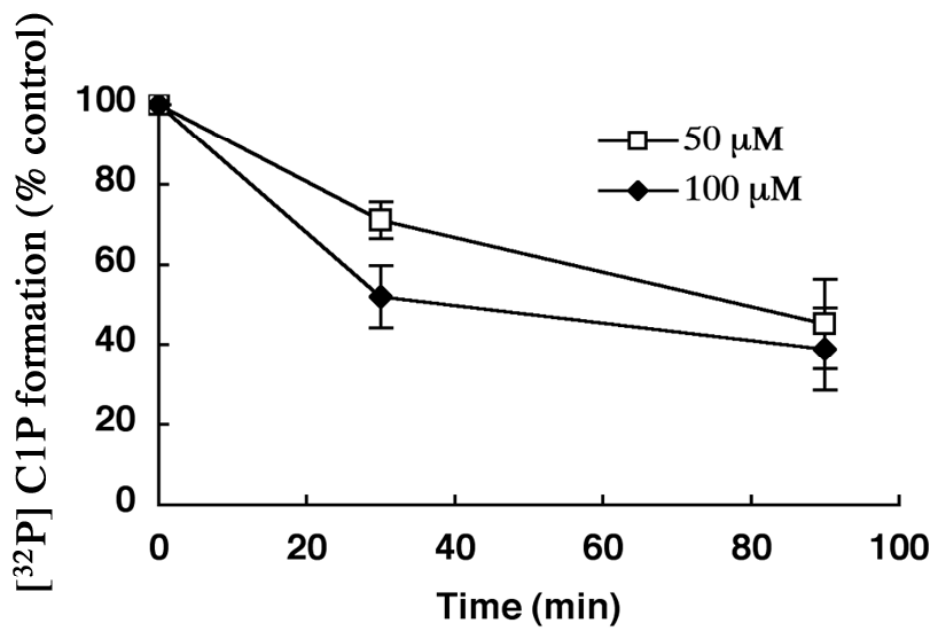

Fig.3

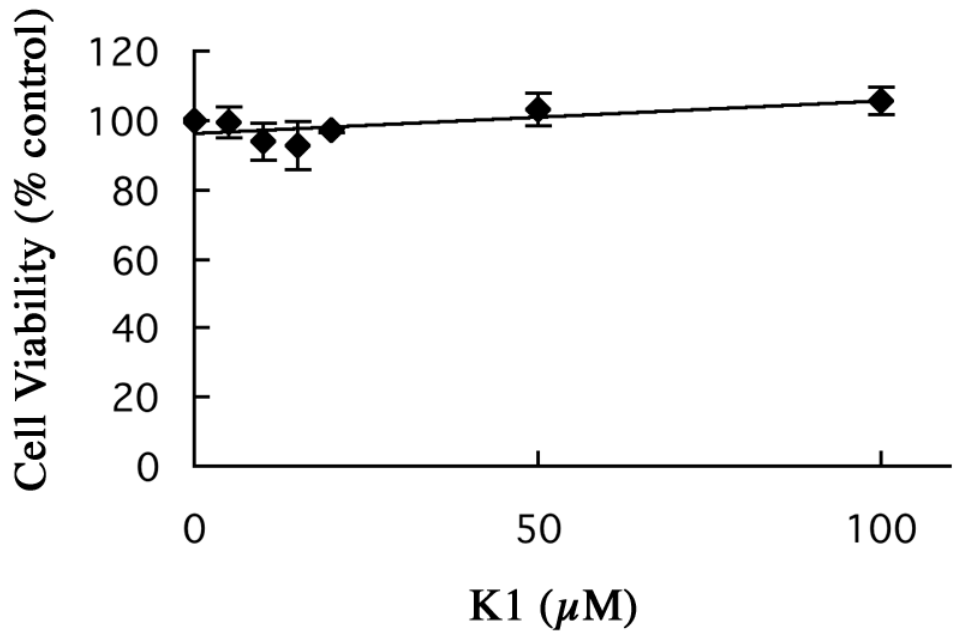


Fig.4A

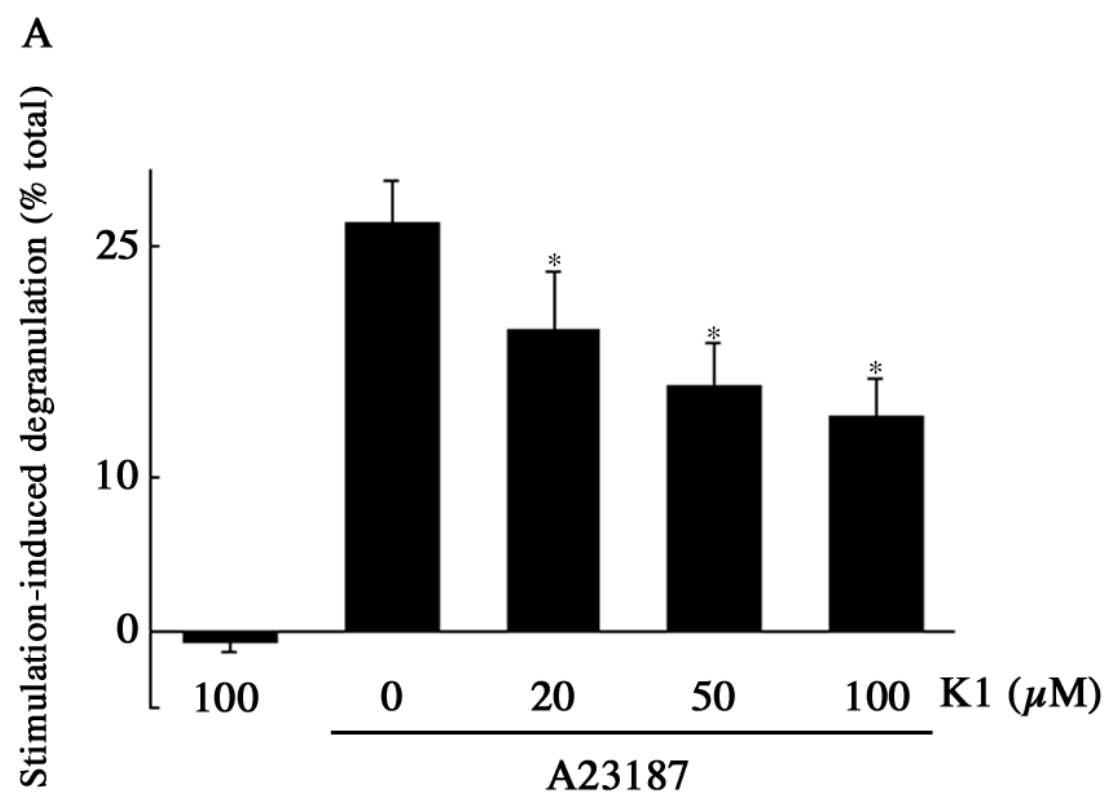

Fig.4B

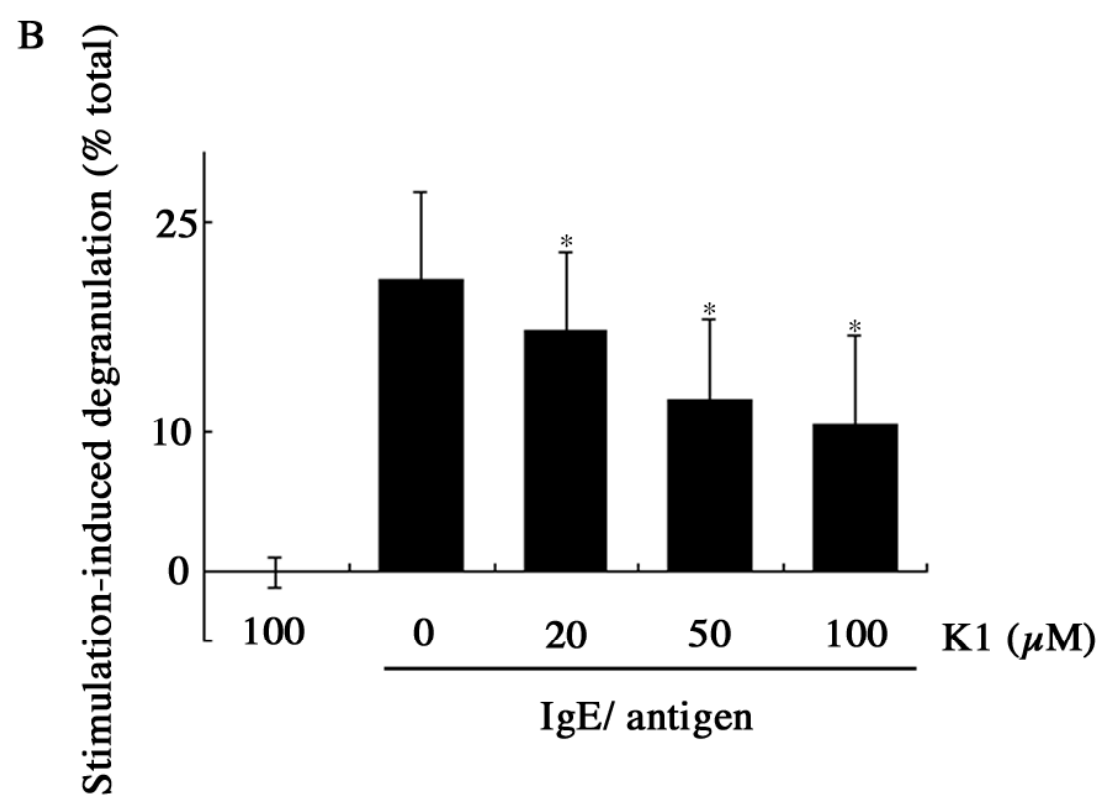


Fig.5A

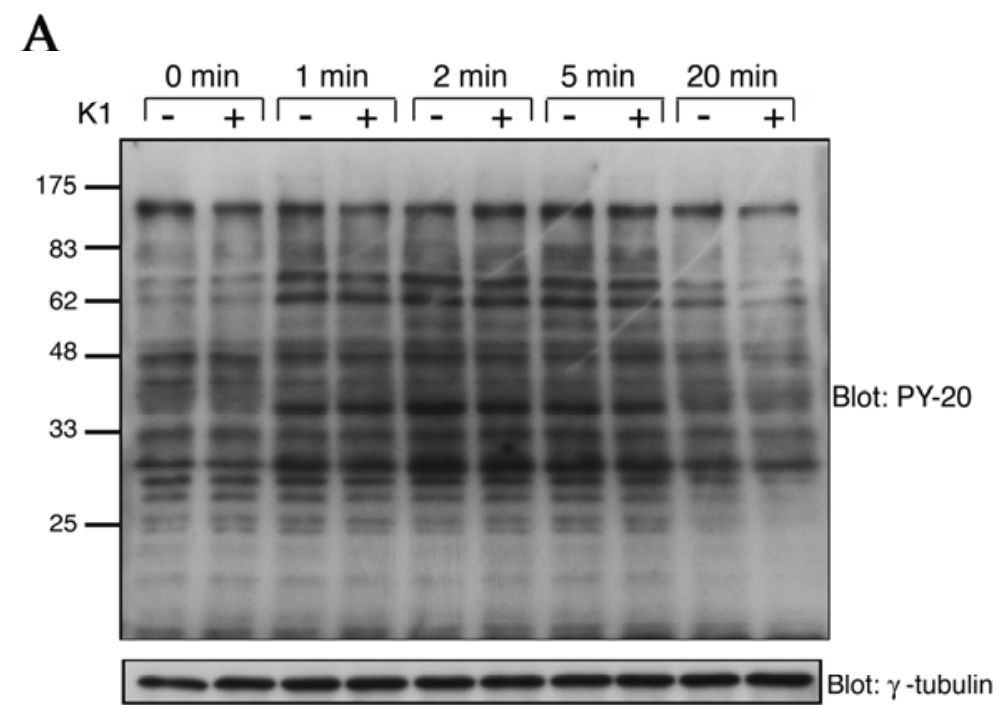

Fig.5B

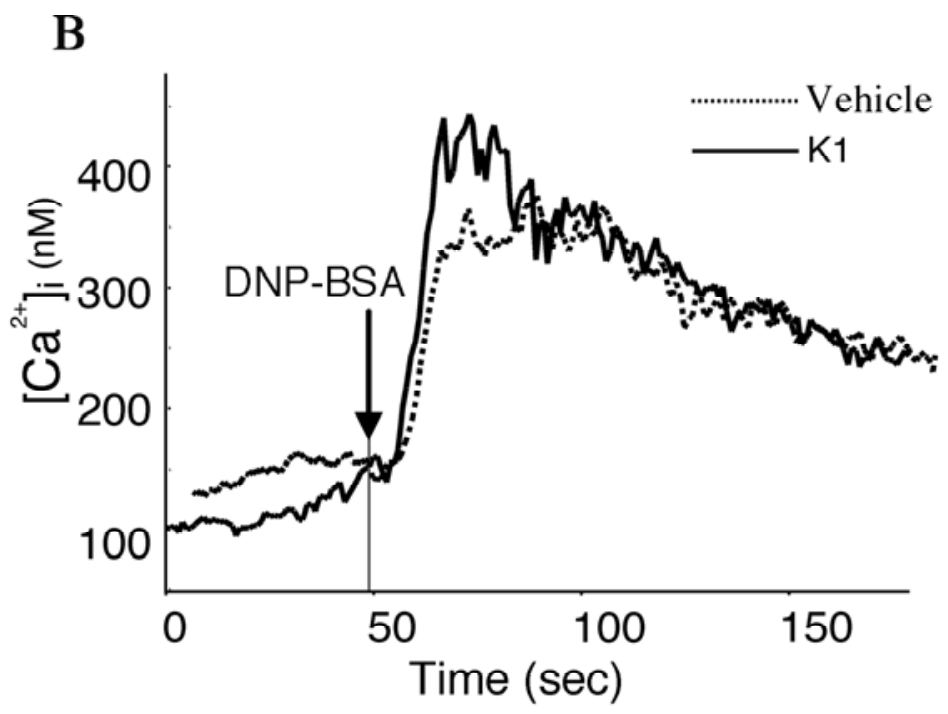


Supplementary Figure 1

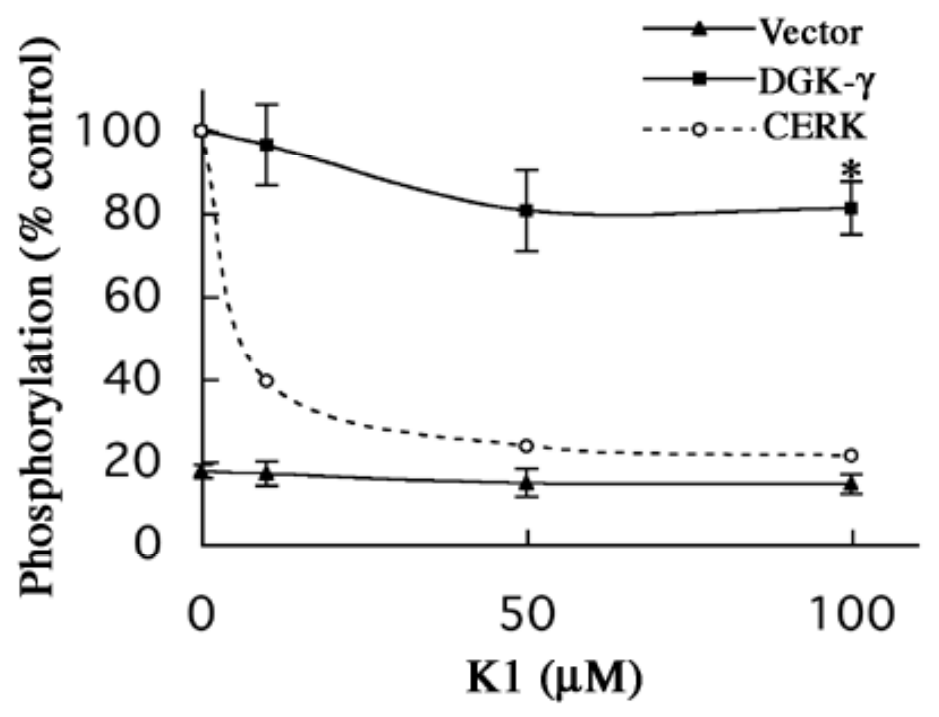




\section{Figure legend}

Fig.1. Inhibition of in vitro lipid kinase activities by F-12509A and its analogs. (A) Inhibition of in vitro mCERK activity by F-12509A, K1 and K2. Lysates were prepared from HEK293 cells transfected with FLAG-tagged mCERK. CERK activities were determined using $\left[{ }^{32} \mathrm{P}\right] \mathrm{ATP}$ and $\mathrm{C}_{18}$-ceramide $(40 \mu \mathrm{M})$ in the presence of increasing concentrations of inhibitors. (B) Effects of K1 on CERK, SPHK1, and SPHK2 activities. In vitro kinase assays were performed using lysates prepared as in (A) or lysates prepared from CHO-K1 cells transfected with HA-tagged hSPHK1 or HA-tagged hSPHK2, and sphingosine $(40 \mu \mathrm{M})$ or $\mathrm{C}_{18}$-ceramide $(40 \mu \mathrm{M})$ as the respective substrate, in the presence of increasing concentrations of $\mathrm{K} 1$. Results are each expressed as a percentage of phosphorylation in the absence of any inhibitor (vehicle; $1 \%$ DMSO) and are the means \pm S.D. of three independent experiments. $*=p<0.05$ versus K1-untreated control.

Fig. 2. Inhibition of C1P production by K1 in intact RBL-2H3 cells. RBL-2H3 cells $\left(1 \times 10^{6}\right.$ cells) were labeled with $\left[{ }^{32} \mathrm{P}\right]$ orthophosphoric acid $(10 \mu \mathrm{Ci})$ at $37^{\circ} \mathrm{C}$ for $30 \mathrm{~min}$. The indicated concentration of $\mathrm{K} 1$ or vehicle was then added, and the cells were incubated for an additional 30 or $90 \mathrm{~min}$. Lipid extraction, alkaline treatment, and thin layer chromatography were performed as described under "Methods." [ $\left.{ }^{32} \mathrm{P}\right] \mathrm{C} 1 \mathrm{P}$ was quantified by a BAS2500 image analyzer. Results are each expressed as a percentage of the value for control cells (vehicle; $1 \%$ DMSO) and are the means \pm S.D. of three independent experiments. 
Fig. 3. Effect of K1 on cell proliferation. RBL-2H3 cells were treated for 24 hours with vehicle ( $1 \%$ DMSO) or the indicated concentration of $\mathrm{K} 1$, and the cell viability was analyzed using a mitochondrial dehydrogenase assay kit. Results are each expressed as a percentage of the value observed for vehicle-treated cells and are the means \pm S.D. of three independent experiments.

Fig. 4. Suppression of RBL-2H3 mast cell degranulation by K1. (A) Effect of $\mathrm{K} 1$ on $\mathrm{Ca}^{2+}$ ionophore-induced degranulation of RBL-2H3 cells. Cells were preincubated for 10 min with vehicle or the indicated concentration of K1. Cells were untreated or stimulated with $1 \mu \mathrm{M}$ A23187 for $40 \mathrm{~min}$. (B) Effect of $\mathrm{K} 1 \mathrm{on} \mathrm{IgE/antigen-induced} \mathrm{degranulation.} \mathrm{Cells} \mathrm{were}$ sensitized with $10 \mu \mathrm{g} / \mathrm{ml}$ anti-DNP IgE for $30 \mathrm{~min}$ at room temperature. Vehicle or the indicated concentration of $\mathrm{K} 1$ was then added, and the cells were incubated for $10 \mathrm{~min}$ at $37{ }^{\circ} \mathrm{C}$. Subsequently, the cells were left untreated or were stimulated with $1 \mathrm{mg} / \mathrm{ml}$ DNP-BSA for 40 min at $37^{\circ} \mathrm{C}$. (A \& B) Degranulation was determined as the $\beta$-hexosaminidase activity in culture supernatants as a percentage of the mean total activity (cells and supernatant). Stimulation-induced $\beta$-hexosaminidase release was then by calculated by subtracting the degranulation of the respective unstimulated control. $*=p<0.05$ versus K1-untreated, stimulated control. Values shown are the means ( \pm S.D. of three independent experiments)

Fig. 5. IgE/antigen-induced global tyrosine phosphorylation and $\mathrm{Ca}^{2+}$ elevation remain intact in the presence of K1. (A) Effect of K1 on FceRI-induced global tyrosine phosphorylation. RBL-2H3 cells were sensitized with anti-DNP IgE, treated with $100 \mu \mathrm{M} \mathrm{K} 1$, and stimulated with DNP-BSA for the indicated times, as described in Fig.4B. Cell lysates were separated on SDS-PAGE then analyzed by Western blotting using an anti-phosphotyrosine antibody (PY-20) (upper panel). The same blots were probed with an anti- $\gamma$-tubulin antibody as a control of sample loading (lower panel). The data are representative of four independent experiments. (B) 
Cells were sensitized with anti-DNP IgE, loaded with Fura-2/AM, and incubated with $100 \mu \mathrm{M}$ $\mathrm{K} 1$ for 10 min. Subsequently, cells were stimulated with DNP-BSA, and $\mathrm{Ca}^{2+}$ mobilization was measured in a fluorescence spectrometer. The data are representative of three independent experiments.

\section{Supplementary Figure legend}

Supplementary Figure1. Effects of K1 on DGK activity. In vitro kinase assays were performed with lysates prepared from HEK293 cells transfected with vector or 3XFLAG-tagged human DGK $\gamma$, and diacylglycerol $(200 \mu \mathrm{M})$ as the respective substrate, in the presence of increasing concentrations of K1. Results are each expressed as a percentage of phosphorylation in the absence of any inhibitor (vehicle; $1 \%$ DMSO) and are the means \pm S.D. of tripricated samples. * $=\mathrm{p}<0.05$ versus K1-untreated control (DGK $\gamma)$. Similar results are obtained in two independent experiments. Results of CERK assay obtained in Fig. 1B are shown for comparison. 